\title{
Theodore Metochites Mosaic at Chora and the Relics of the True Cross
}

\section{Kariye'deki Theodore Metokhites Mozaiği ve Gerçek Haç'ın Kalıntıları}

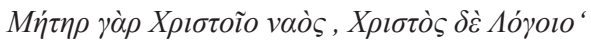 \\ ("The Mother was a temple for Christ, while Christ \\ was a temple for the Logos ", To Nemesius, PG 37, 1565A)
}

Jasmina S. ĆIRIĆ*

(Received 14 January 2021, accepted after revision 09 August 2021)

\begin{abstract}
This article aims to analyze the ktetorial composition depicted above the west portal of the Chora Church (Kariye Camii). Although many researchers provided a description of this composition, the representation of the church in the hands of Logothetes tou Genikou, Theodore Metochites, has not been specifically examined. No matter that the church is depicted with the majority of the architectural elements which correspond to the reality, it is interesting to notice that two large crosses are depicted laterally of the west portal. These crosses do not correspond to the elements of the brickwork of the west facade. Nevertheless, careful analysis of the marble portal between naos and narthex area contains quite particular detail: in the lower third of two jambs of the portal were inserted pectoral crosses (encolpia) which testified to the keeping of small particles of the True Cross relic, hope for salvation and inscribing of the ktetor in the circle of the protected by True Faith.
\end{abstract}

Keywords: Theodore Metochites, the Chora church, ktetorial composition, mosaic, relics of the True Cross, pectoral crosses, marble portal.

\section{Öz}

Bu makale Khora Kilisesi'nin (Kariye Camii) batı portalının üzerinde tasvir edilen bani sahnesini analiz etmeyi amaçlamaktadır. Kompozisyon birçok araştırmacı tarafindan tanımlanmasına rağmen, Büyük Hazinedar (Logothetes) Theodore Metokhites'in elindeki kilisenin temsili özel olarak incelenmemiştir. Kilise gerçeğe karşıllk gelen mimari unsurların çoğu ile tasvir edilmesine rağmen, batı portalın yanlamasına tasvir edilen iki büyük haç motifini fark etmek ilginçtir. Bu haçlar batı cephesinin tuğla örgüsünün unsurlarına uymuyor. Ancak, naos ve narteks arasındaki mermer portalın dikkatli analizi oldukça özel bir detay içermektedir: portalın iki sövesine pektoral haçlar (encolpia) yerleştirilmiştir. Bu pektoral haçlar, ktetor'un Gerçek Inanç tarafindan korunma ve kurtuluş umuduna tanıklık ederek Gerçek Haç rölik parçalarının kilisede saklandiğını göstermektedir. Ayrıca, ktetor'un kurtuluş için umudu ve Gerçek Inanç tarafindan korunan daireye kaydetmesini simgelemektedir.

Anahtar Kelimeler: Theodore Metokhites, Khora Kilisesi, bani sahnesi, mozaik, Gerçek Haç, pektoral haçlar, büyük kapl.

\footnotetext{
Jasmina S. Ćirić, Faculty of Philology and Arts, University of Kragujevac, Serbia. ciric@filum.kg.ac.rs; jciric0905@gmail.com

This article is the result of the research carried out within the framework of two national scientific projects: "Christian culture on the Balkans in Middle Ages: Byzantium, Serbs and Bulgars from $9^{\text {th }}$ to $15^{\text {th }}$ century" $(177015)$ and "Medieval Art in Serbia and its European context" (177036) financed by the Ministry of Education, Science and Technological Development of Republic of Serbia. The article also belongs to the research within the European multilateral international project: COST Action CA19131 "Europe Through Textiles: Network for an integrated and interdisciplinary Humanities".
} 
In Byzantium those who had built, restored, reconstructed a church often had themselves portrayed as ktetors in front of the holy figure to whom the church was dedicated (Velmans 1977: 69-97; Kalavrezou-Maxeiner 1991: 1705; Danker 2000) ${ }^{1}$.

Within the repertoire of the architectural depictions in later Byzantine art, ktetors and representations of the church in the hands of the commissioners have a specific ideological background (Kazhdan 2000: 1160) ${ }^{2}$. The representation of ktetor portrayed with a model of the church is connected with a deep eschatological model of thinking. The Last Judgement sets the agenda for every Christian. Likewise, the ktetor expresses hope for his salvation and redemption of his soul, whose pledge is the church which he offers to Christ, is one of the basic stimuli of the ktetorial activity (Grabar1971: 106-111) ${ }^{3}$. The aim of this article is to analyze in detail ktetorial (donor) mosaic composition depicted above the west portal of Chora Church / Kariye Camii (Fig. 1). The art of the Chora has attracted an enormous amount of attention in scholarship over the years. The Chora is the most celebrated monument of the second decade of the $14^{\text {th }}$ century AD (Underwood 1966; 1975; Hjort 1979: 199-289; Ousterhout 1987; Ousterhout 2002; Klein et al. 2011)4.

Within the scope of new discoveries it is possible to discuss the Chora Monastery in ways that are simply not feasible at almost any other site.

Theodore Metochites, who was for some years Logothetes tou Genikou (prime minister) of the Byzantine Empire, the richest citizen after the emperor Andronikos II, lavishly and richly restored the church of Chora (Fig. 2). That

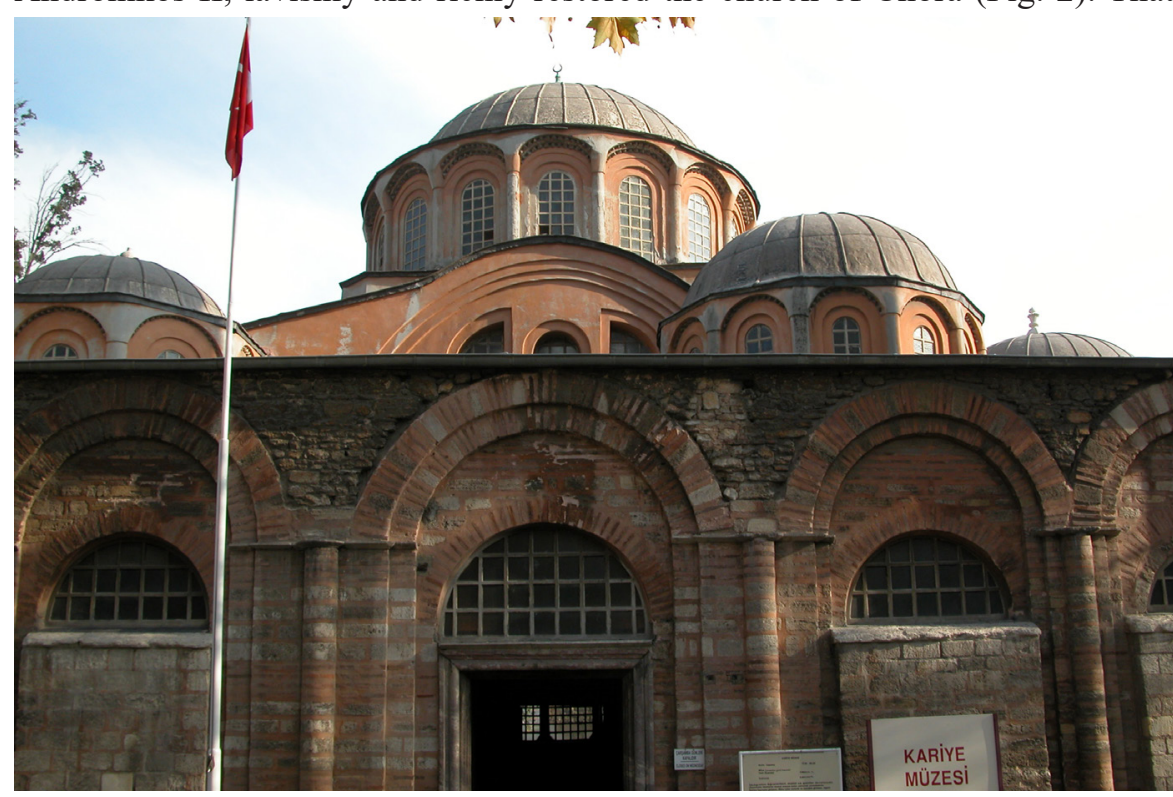

1 The word ktetor derives from the Greek $\kappa \tau \dot{\alpha} o \mu \alpha l$, which in ancient Greek means "to acquire," and by Late Antique times comes to mean "to possess" or "to own".

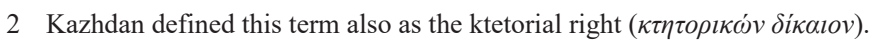

3 Ktetorial composition is also the term which is often used in the historiography. Andre Grabar used to identify this composition also as "offrande de l'empereur".

4 Chora $(\mathrm{X} \omega \rho)$, which in Modern Greek means village or the capital of an island. The word chora also has other meanings, such as container, dwellingplace, or keep (donjon or fortress) and the name of the monastery came to be reinterpreted in a mystical sense. In the pendant images at the entrance, and throughout the building, Christ is entitled as $\dot{\eta} \chi \omega \dot{\omega} \rho \alpha \tau \tilde{\omega} \nu \zeta \dot{\omega} v \tau \omega v$ : The Dwelling-place of the Living, a reference to Psalm 116:9, a verse that appears in the funeral liturgy, a reference to our heavenly reward - here a play on the name of the monastery. The literature on the building is now voluminous. In this case is quoted only selected titles among many others.

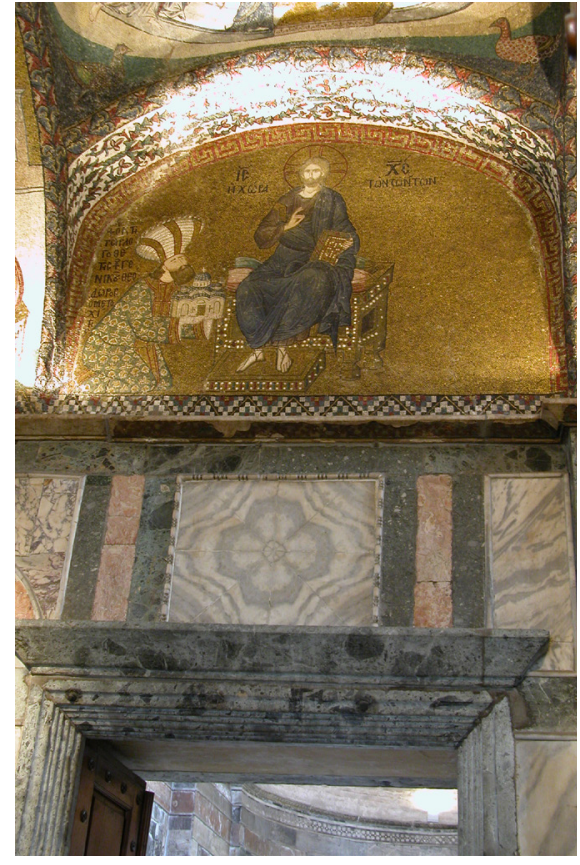

Figure 1

Theodore Metochites presenting the church to the enthroned Christ, mosaic above the entrance to the naos, Chora church (Kariye Camii), İstanbul. Photo: Jasmina S. Ćirić.

Figure 2

Chora Church (Kariye Camii), west facade. Photo: Jasmina S. Ćirić. 
Figure 3

Theodore Metochites presenting the ktetorial model. Photo: Jasmina S. Ćirić.

restoration was very extensive. Since only the nave of the Komnenian building remained, at the beginning of the $14^{\text {th }}$ century $\mathrm{AD}$, a dome, pastophoria, and side annexes with narthex and exonarthex with domes were added to it (Ousterhout 1987: 35). Precisely, Metochites provided for the entire space to be redecorated, including the surviving marble revetments and floors, as well as the partially surviving mosaics.

At the same time, he enveloped the older building with new additions. The pastophoria were rebuilt and decorated with mural paintings; a two-storied annex was added to the north side of the naos; two narthexes were added to the west, lavishly outfitted with marbles and mosaics; and a funeral chapel or parekklesion was added to the south, decorated with frescoes. At the southwest corner, where the minaret now rises, a belfry was constructed, also decorated with Metochites' monograms in brick. According to Ihor Ševcenko, Andronicus II gave to Theodore Metochites the title of ktetor. Moreover, Metochites's words provide an intimate assessment of his role as patron (Featherstone 2000: $225)^{5}$. That is exactly the reason why Metochites holds a model of the church he patronized in the lunette above the west portal with the church in his hands as if he was the one who established the monastic structure and was the founder of the monastery (Fig. 3) (Ševčenko 1975: 29 note 76). Although many researchers

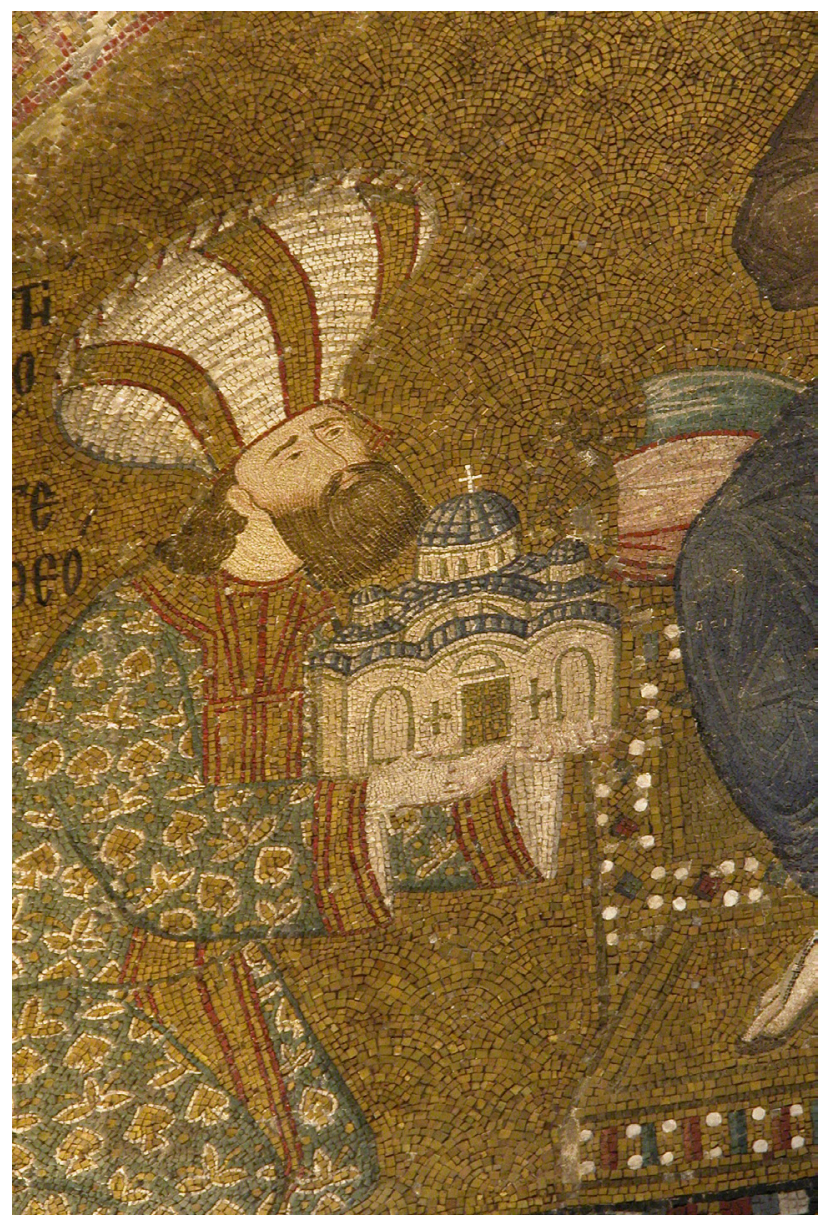

5 Metochites described his personal motivations as follows: "Now, Time which carries off all good things in its current had all but consigned this monastery to ruin. But the emperor desired to raise it up and restore it as it had been formerly; and he urged me on to this work with force - desirous as I myself was - to oversee this offering in all ways most pleasing unto God, this exceeding delightful favor to the emperor and gain for our soul and unperishable renown through all ages, if only I could shore it up firmly and make it in all ways more secure than before - as indeed it now is - and thereby bring before God and before the emperor such an immense and right glorious gift". Featherstone 2000: 225. 
analyzed this composition, honoured the mosaics and frescoes themselves with many descriptions and intriguing interpretations, the representation of architecture in the hands of Theodore Metochites, ktetor of Chora church, was not of particular scientific interest. It is curious, that in the pricipal historiography of the Late Byzantine art, ktetorial model - model of the church depicted above the portal, is scarcely mentioned. To explore this question, this essay will consider description of the ktetorial composition. Second and more relevant, this essay will argue what might be depicted within the model of the church - more specifically around the representation of the portal, according to the preserved material remains.

Project of the restoration in Chora embodies the idea of potent symbols of imperial power, and it is for this reason that ktetor is honoured with mosaic depiction with golden tesserae, underlining the inscription of the True Faith (Nelson 1999: 67101). Cyril Mango recognized this composition as embodiment of Metochites's snobbery (Mango: 1959: 142).

Above the west entrance to the naos, where Metochites is shown with his high hat (Popović 2010: 91-117), offering the church to Christ, the inscription states

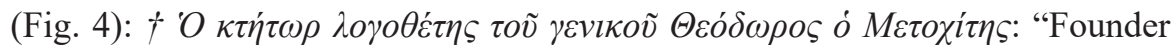
and Minister of the Treasury Theodore Metochites" (Ševčenko 1975: 19- 55; Magdalino 2011: 169 -87). "The Living library" or the greatest scholar of his day, Metochites in both hands holds a model of the Church. This depiction of the church is quite peculiar in later Byzantine art since the church is depicted frontally. Although some authors considered that the church is depicted more symbolically and ideally since the reality of Chora is absent (Azara 2001: 440), e.g. there is no literal connection with the real image of the facade of Chora, it is our assumption that this representation corresponds to the real appearance of the building. The church in the hands of Theodore Metochites, fully and in detail reflects the appearance of the western facade of the church. The representation of the church shows the largest number of elements of the church: the main dome, two lateral domes of the exonarthex, the roof structure depicted with usage of the upper perspective, and the white color of the west façade (Ousterhout 1987: 35-36 pl. 2, 4).

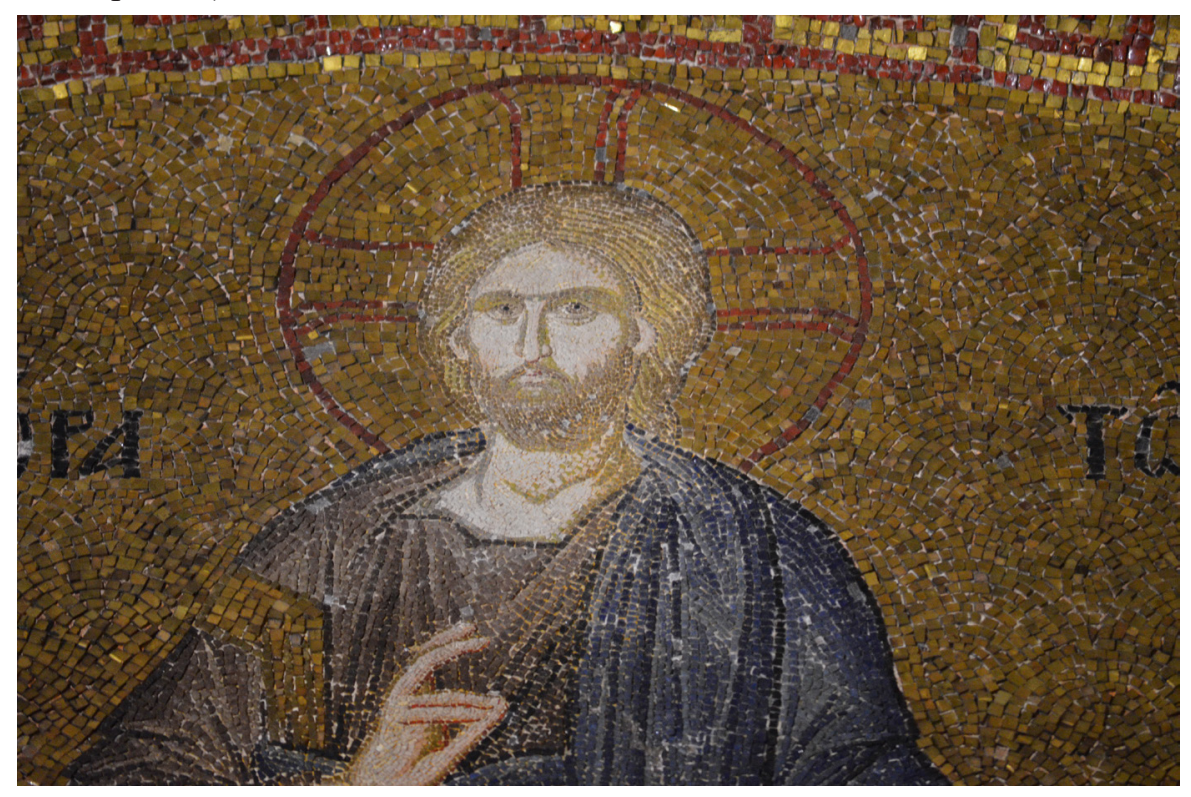

To the side of the main dome are two lateral domes of the same size. In reality, the north dome above the narthex is smaller, has twelve registers and a smaller
Figure 4

Christ and glittering of the mosaic. Photo: (C) David Hendrix / The Byzantine Legacy. 
Figure 5

Ktetorial model in the hands of Theodore Metochites. Photo: (C) David Hendrix / The Byzantine Legacy.

number of openings in comparison with the dome compared to the south, which has twenty-four segments. The central dome is depicted realistically, with the same amount of openings that are, from one point, visible on the actual building.

The west façade consists of three registers (Fig. 5). Each register contains one arched pediment which resembles a blind niche or lunette. In midst of the façade predominant is depiction of the portal divided by six rectangular fields, and above is a lunette depicted without a patron of the church. To the side of the portal depicted with golden tesserae are arched fields. To the left and right of the golden door are two crosses of almost the same dimensions as the portal depicted in the center.

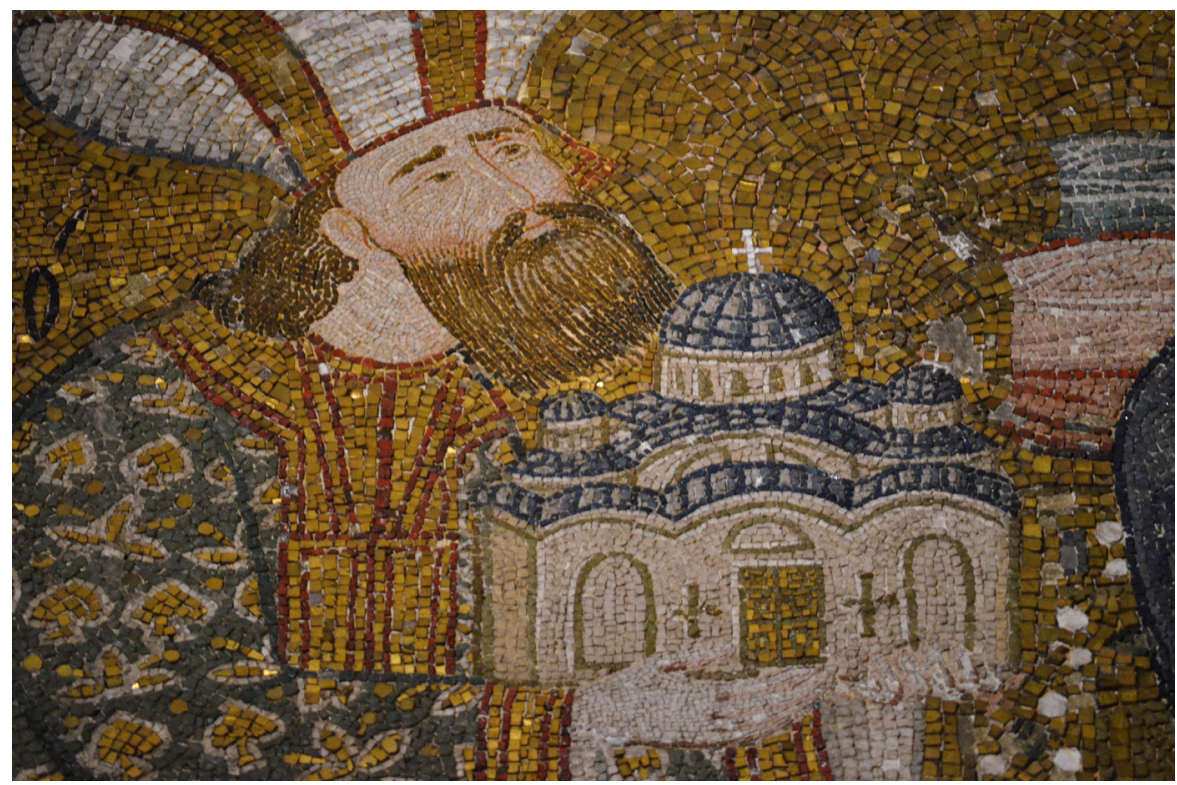

Some of the issues involved in defining of the ktetorial model is given by white color of mosaic tesserae which is used for the "façade". On the white background of a model is visible golden portal flanked by two crosses which are almost the same size as the portal. It is completely clear that there are no preserved brick ornaments reminiscent to a cross on the façade. It can be rather said the mosaicist's tendency was to emphasize these geometric crosses within a model of the church. Yet, in addition to this, another argument seems to indicate a move toward the reading of ktetorial composition and the meaning of a model: the golden portal. As a first step in reconsideration of the image, it is necessary to recall the Golden Gate of Constantinople, but also the Golden Gate of Jerusalem where Joachim and Anne had met (Matheou et al. 2016: 213). The glimmering tesserrae of the mosaic background and the portal are juxtaposed and much that is visible is that its patron did not spare any expense. Mosaic with glimmering tesserae remains the costliest medium which mirrors the pretensions of the monument and a person who paid for its adornment. Glimmering light of the Golden Door is an active force in the golden picture (aurea pictura) creating the impression that the worshippers are embraced by the daylight, "living" light that embedded Christ's presence even more deeply into the sacred building. Light made of golden teserrae was alive in a more particularly Christian sense, as they played with ideas of incarnation and embodiment that were central to Christian belief(James 1996: 106-107, 121-123; Janes 1998: 18-42; Bührer-Thierry 2004: 521-556; Schibille 2014). The structures of light contained in the background of this mosaic move, bend, spring up, stretch, and even dance. Glimmering works 
to produce sacredness of the interior. If we follow the arguments of Nicoletta Isar that the choral pattern happens in the Church leading toward the divine and eternal, it means that golden tesserae turn the image and interior into a container of light in motion (Isar 2006: 59-90).

Last but not least, it is necessary to explain the meaning of the crosses on the model, as the third axis within which it is necessary to interpret this mosaic. Evocative physical evidence is embodied in the west portal of naos. It preserves evidence of keeping the memory of True Cross. During my scholarship at Koç University provided for the Summer Programme "Istanbul through the Ages" held in July and at the beginning of August 2012 th , I worked on a detailed photographical study of the ktetorial mosaic at Chora. In the lower third of the marble portal jambs I noticed deeply carved crosses, shaped specifically thinner in the upper part, so that it is quite noticeable that it served to receive precious metal content: votive set of pectoral crosses (Figs. 6, 7, 8). These crosses which
Figure 6

Left cross on the jamb of the west portal to the naos. Photo: Jasmina S. Ćirić.
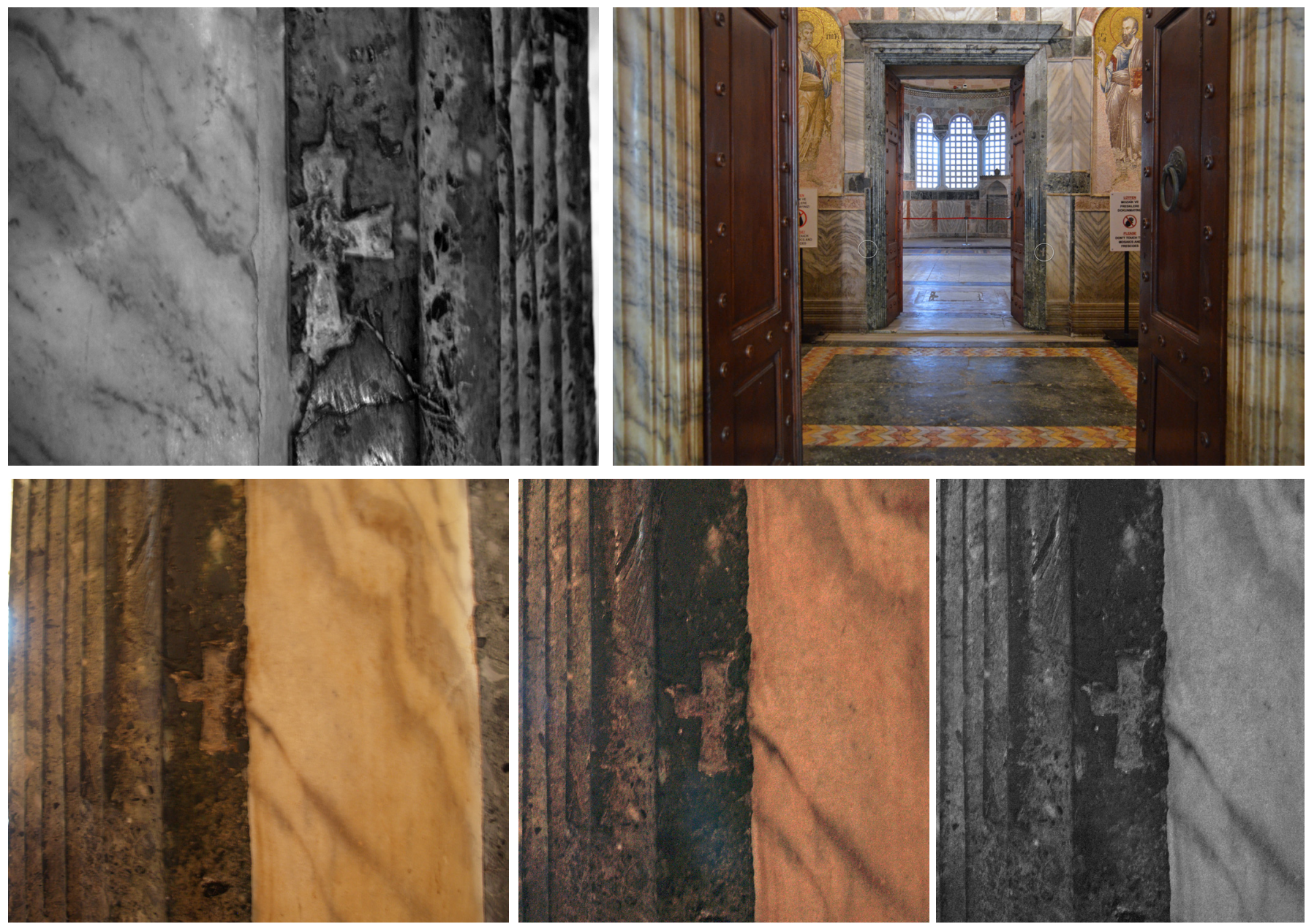

testified to the efficacy of the cult, served as a protective device for keeping and admiration of small particles of the True Cross (Cvetković 2020: 115-123). Crosses refer to Christ as the "light" and "life" ( $\varphi \tilde{\omega} \zeta \zeta \omega \tilde{\eta})$ of the world, as in John 8:12: "I am the light of the world; he who follows me will not walk in darkness but will have the light of life." Similar crosses are found at the main portal of St. Catherine church at Sinai (Filotheu 2008: 77-78) but most of all in Hagia Sophia in Constantinople. Spatially similar to Chora church, two crosses are found in the inner narthex of Hagia Sophia (Figs. 9a, b, c). In the green marble band
Figure 7

Right cross on the jamb of the west portal to the naos. Photo: Jasmina S. Ćirić.

Figure 8

Right cross on the jamb of the west portal and view toward the naos. Photo: Jasmina S. Ćirić. 

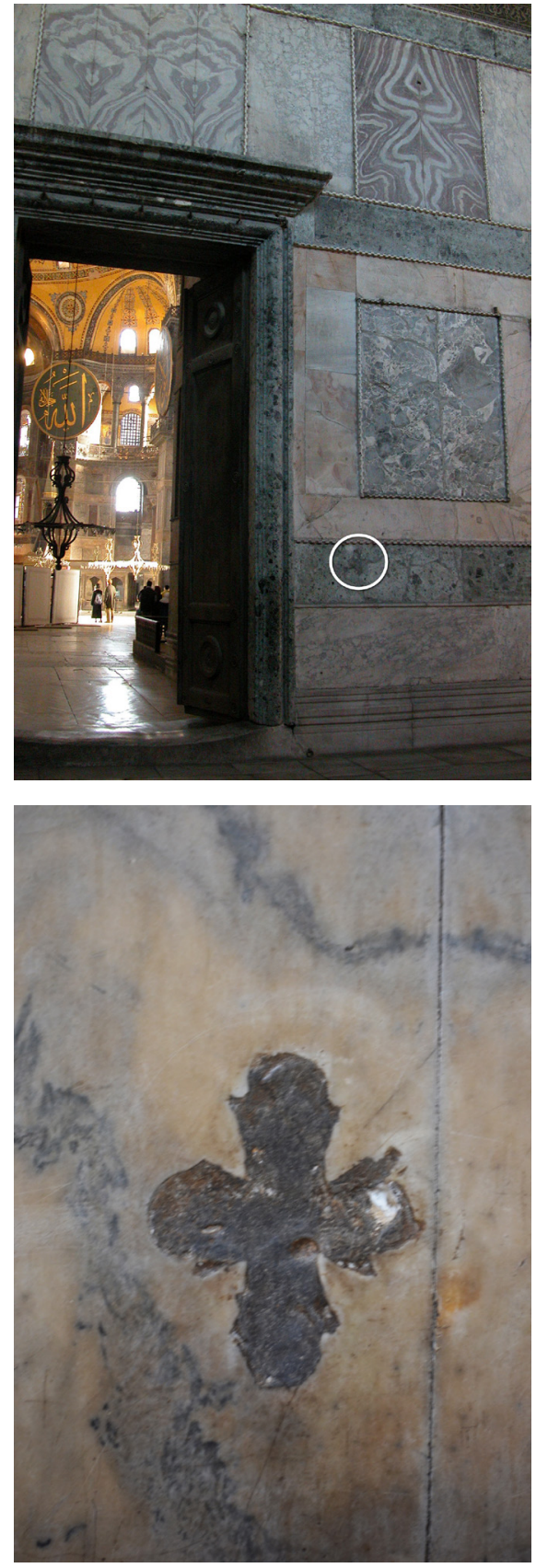

Figure 9a

Portal of the inner narthex with visible crossshaped cavities, Hagia Sophia, İstanbul. Photo: Jasmina S. Ćirić.

Figure $9 b$

Marble between two portals in the inner narthex of Hagia Sophia. Photo: Jasmina S. Ćirić.

\section{Figure 9c}

Portal of the inner narthex with visible crossshaped cavities, Hagia Sophia, İstanbul. Photo: (C) David Hendrix / The Byzantine Legacy.

Figure 10

Gallery of Hagia Sophia, marble with visible cross-shaped cavities. Photo: CDavid Hendrix / The Byzantine Legacy.
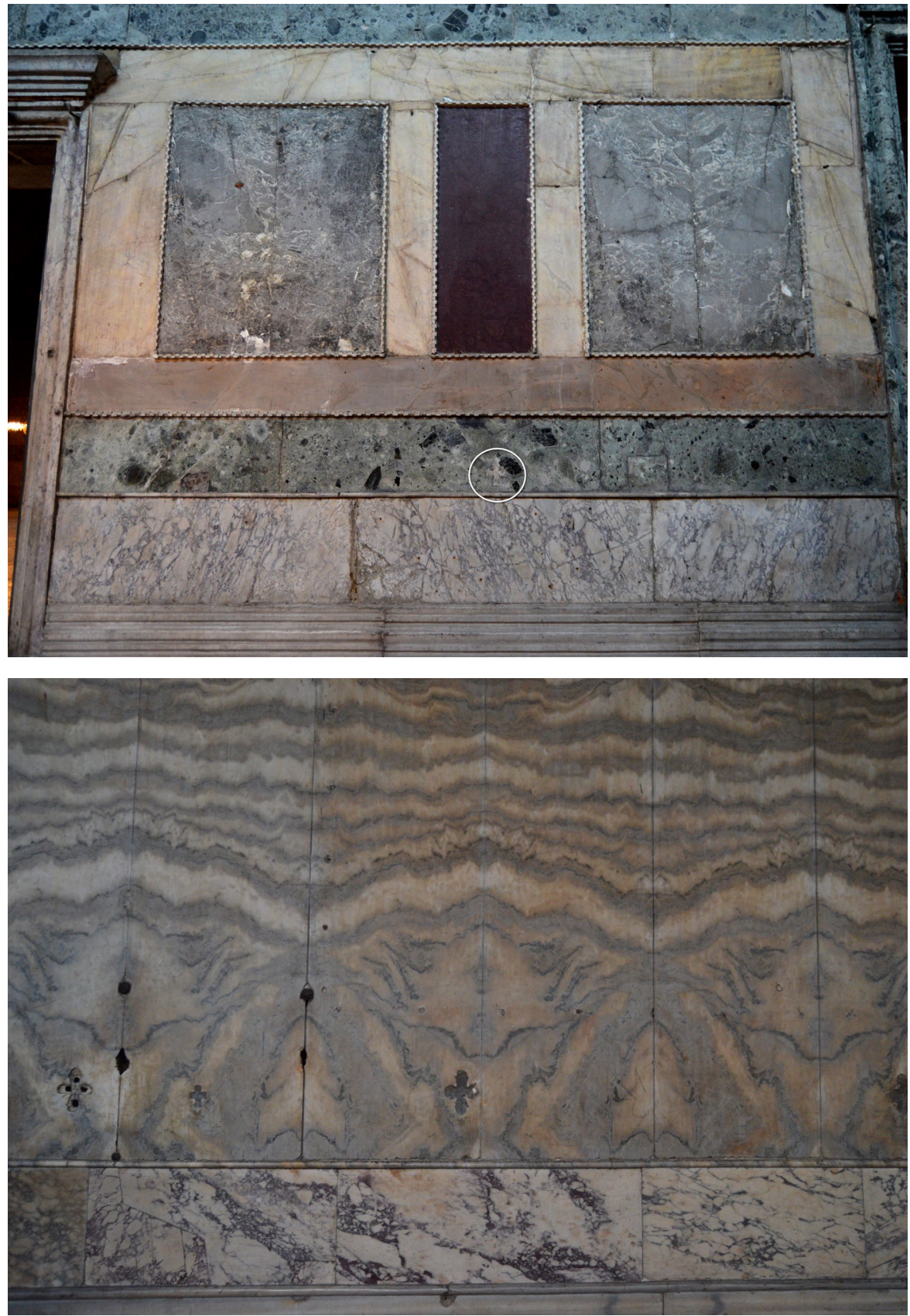

between the second and third doors from the north and between the central and fourth doors (Teteriatnikov 1998: 432). Also, cross-shaped cavities are visible at the eastern wall of the western gallery and at the south side of the western gallery (Fig. 10) (Teteriatnikov 2003: 74-92). Intervisual context between two churches, is additionally empowered by the fact that crosses in Chora are found almost in front of the composition Deesis. At the gallery of Hagia Sophia crossshaped cavities are visible in the spatial unit which follows west wall of the south gallery also known because of the preserved mosaic of Deesis (Nelson 1999: 67-101, esp. 71, 77). Having in mind that the beholder moves from the west toward the east, it means that procession functioned from the interior narthex through the west portal between narthex and naos. In the domical vault above this portal is Eisodia Theotokou or the Entrance of Mary to the Temple (Fig. 11), it is relatively easy to understand visual construct with the idea of the entrance underlining (Lafontaigne-Dosogne 1975: 220-223; Evangelatou 2019: 92). All 


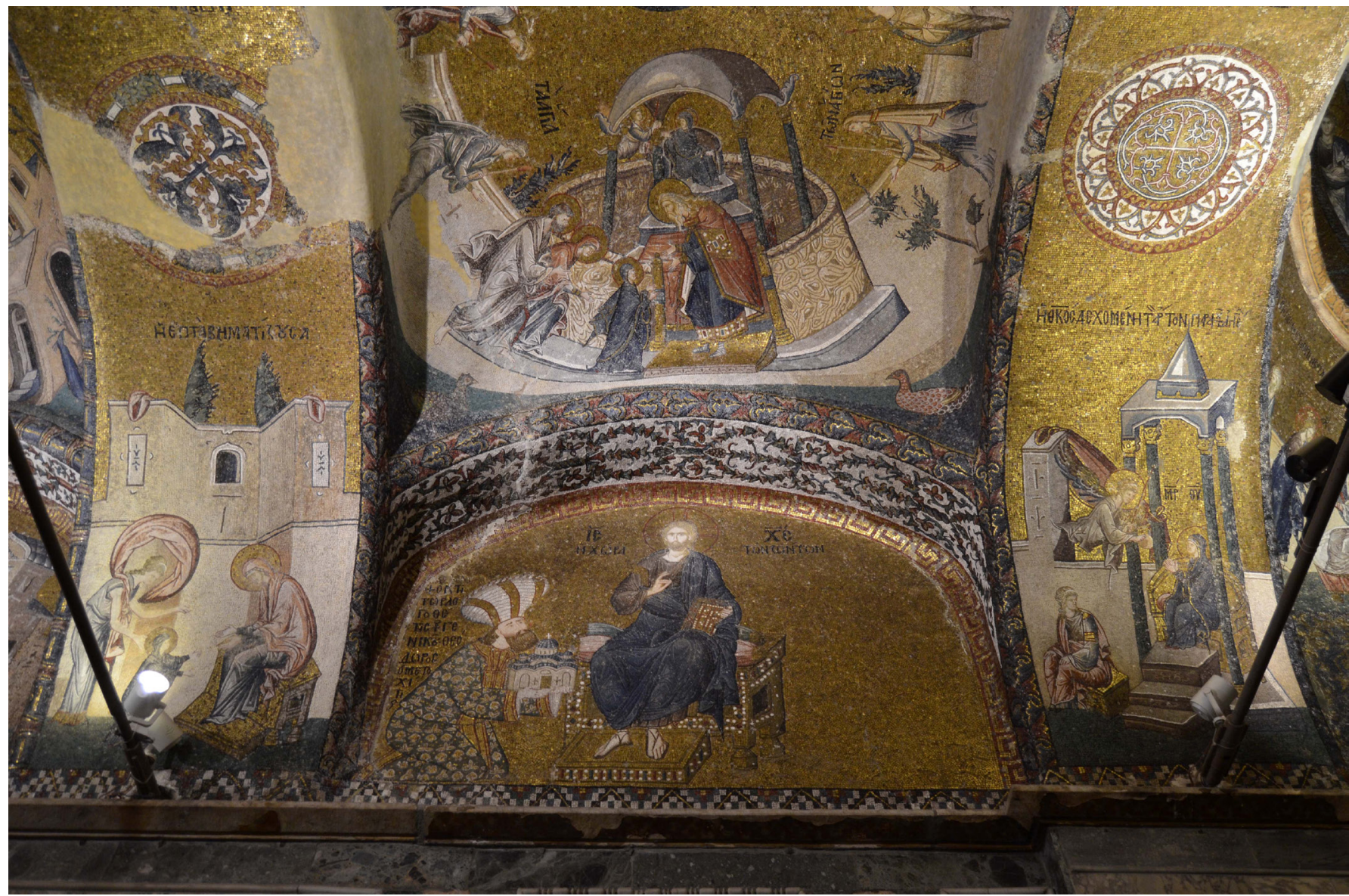

of these visual underlining would have resonated in the eyes of the Byzantine viewers. Eisodia Theotokou as focal point for the gaze of the viewers evoked the idea of Mary as the variety of exegetical images based on allegory or metaphor of the Temple (naos) of Jerusalem and its gate: "Having opened the gates and entrances, the Temple receives the gate of God, the King of all, and adorns the inner parts. At her entrance, the Temple is illuminated with grace" (Olkinoura 2015: 281$)^{6}$

Theodore Metochites before Christ, mosaic in the inner narthex, is flanked by depiction of the Holy Apostles, St Peter and St Paul (Fig. 12). Such mosaics are the closest images to the beholder. The towering figures of Theodore and Christ can hardly be ignored. Theodore in submissive position makes an effort to establish communication before the Christ. That is evident in the manner he proffers the ktetorial model with both hands showing his piety and hope. Worshippers would cross from the exonarthex inside of the area of narthex and through the narthex they would enter in the area of naos through the west portal adorned with pectoral crosses. This triangle, Metochites, model and crosses that flank the west portal, recreate the act of passage and holyness inside additionally underlined with the panel of Dormition of the Virgin above the portal and with

6 The fact that Eisodia is connected with the idea of portal and the Cross is additionally visible at the south portal of narthex of Chilandar katholikon at Mount Athos. The south portal contains two inserted crosses in the jambs of the portal. Crosses were inserted between the particles of stone, in the mosaic-like picture with the illusion of depth which resembles to the particles of the floor (Boškovic 1959: 130). The fact that crosses were inserted in the portals of Serbian churches was not previously researched. It is intriguing the fact that in the axe of the lintel of west portal between narthex and naos of the Virgin's church in Studenica are preserved traces of two crosses. Most probably these crosses marked the position of pectorals. About martking of the portal with the cross there are several descriptions within Serbian written sources (Trifunović 1973: 172).
Figure 11

The Entrance of the Virgin in the Temple, mosaic in the domical vault above the west portal. Photo: Jasmina S. Ćirić.

Figure 12

Apostle Paul, mosaic in the left niche with visible north jamb of the west portal and cross-shaped cavity in the lower third of the jamb. Photo: Jasmina S. Ćirić.

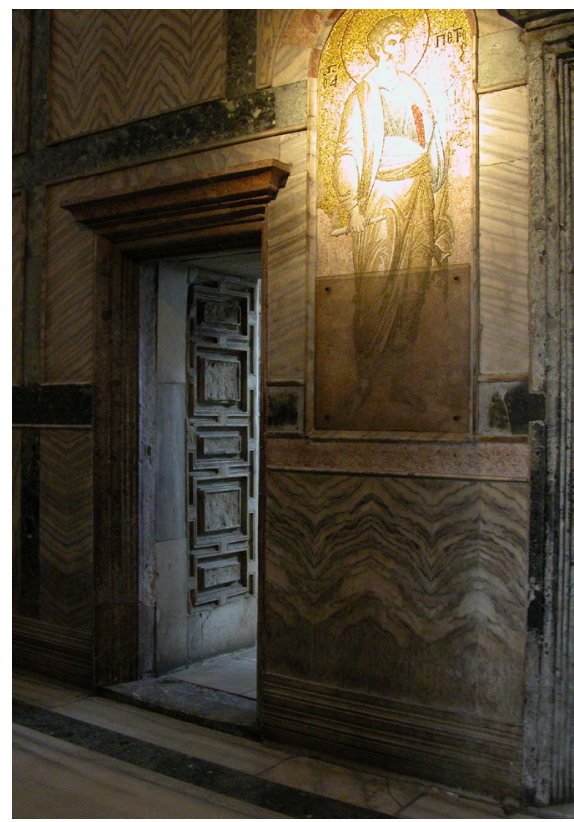


Figure 13

Dormition of the Virgin Mary, mosaic in the naos, above the west portal.

Photo: (C) David Hendrix / The Byzantine Legacy. the composition above in the vault where is the mosaic of the Entrance of Mary to the Temple (Fig. 13) (Ousterhout 1995: 91-108). Imagological speaking, this spatial area marked with the portal, pectoral crosses and two mosaics became the embodiment of the solemn Sanctification of the Water. Because of the illnesses

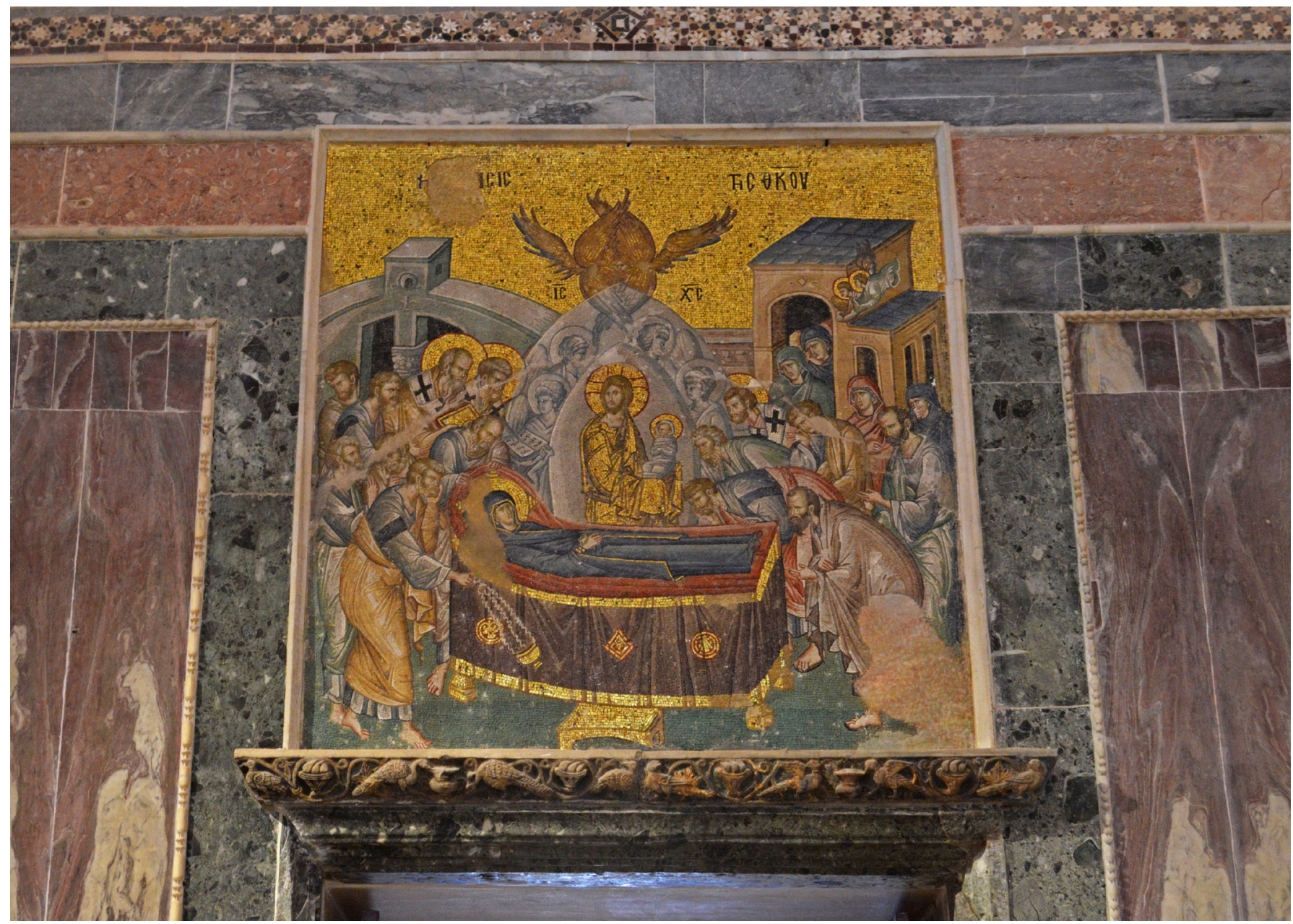

that often occur in August, the custom took root long ago in Constantinople of carrying out the Honorable Wood of the Cross into the streets to sanctify the places and avoid illness. On the eve, July 31 , the Wood was taken out of the royal treasury and placed upon the holy table of the Great church (Hagia Sophia). From this day until the Dormition of the Mother of God, processions were served all over the city and the cross was offered to the people for veneration. This is that very procession $(\pi \rho o o \delta o \varsigma)$ of the Honorable Cross. Another custom was joined to this one: to sanctify the water in the church of the royal court in Constantinople on the first day of each month, with the exception of January, when the water was sanctified on the $6^{\text {th }}$, and September, in which it occurred on the $14^{\text {th }}$. These two customs lie at the foundation of the celebration of the All-Merciful Savior, Christ our God, and His Mother the Most Holy Theotokos, Virgin Mary on $1^{\text {st }}$ August. On the same day the "Procession of the Honorable Wood of the Cross of the

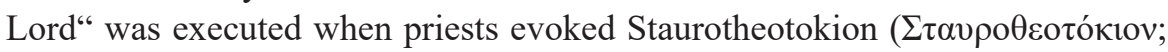
Foley - Bangert 2000: 289; Bulgakov 2009: 69), a hymn commemorating the Blessed Virgin at the cross and the attending solemn sanctification of the water (Klein 2006: 79-99; 2015: 201-212). Through the synergy of spatial articulation, the symbolism of forms and their shaping as choral movement and auditive 
image, in presence of the relics of the True Cross as well as a specific mosaic program, the whole church was metaphorically transformed and linked with the image of the Garden of Eden and Land of the Living ( $\dot{\eta} \chi \dot{\omega} \rho \alpha \tau \tilde{\omega} v \zeta \dot{\omega} v \tau \omega v)$.

The function of Theodore's portrait and ktetorial model served as preservation of the memory on the relics of True Cross, reflection of the miraculous belief in contact between natural and supernatural, between humanity and divinity, opening of the field of mystery contained in the Cross, the Savior and His victory over death (Evangelatou 2019: 92). Thus, the west portal became not only the container of the mystery of the Crucifixion, but also struggles, temptations and sufferings of the Mother of God at the foot of the Cross since she is hailed as container and provider of eucharistic body of Christ.

\section{Bibliography - Kaynaklar}

Azara 2001

Bošković 1959

Bulgakov 2009

Bührer-Thierry 2004

Cvetković 2020

Danker 2000

Evangelatou 2019

Featherstone 2000

Filotheou 2008

Foley - Bangert 2000

Grabar 1971

Hjort 1979

Isar 2006

James 1996

Janes 1998

Kalavrezou-Maxeiner 1991

Kazhdan 2000

Klein 2006

Klein et al. 2011
P. Azara, La representation des modeles dans l'art ancien: un embleme de la creation architecturale? Maquettes architecturales de l'Antiquite, Actes du colloque de Strasbourg, Paris.

Đ. Bošković, "Sur quelques maîtres - maçons et maître - peintres des premieres décades du XIV e s . en Serbie et en Macédoine", Starinar 9-10, 125-131.

S. Bulgakov, The Burning Bush: On the Orthodox Veneration of the Mother of God, Cambridge.

G. Bührer-Thierry, "Lumière et pouvoir dans le haut moyen âge occidental. Célébration du pouvoir et métaphores lumineuses", MEFRM 116.2, 521-556.

B. Cvetković, Enkolpion and Pectoral $\left(12-14^{\text {th }}\right.$ Century), Trsat Reliquary: History-Epigraphy-Iconography, Jagodina, 115-123.

F. W. Danker (rev. and ed.), A Greek-English Lexicon of the New Testament and Other Early Christian Literature, Chicago.

M. Evangelatou, "Krater of Nectar and Altar of the Bread of Life: The Theotokos as Provider of the Eucharist in Byzantine Culture", T. Arentzen - M. Cunningham (eds.), The Reception of the Virgin in Byzantium: Marian Narratives in Texts and Images, Cambridge, 77-119.

J. M. Featherstone (ed. and trans.), Theodore Metochites's Poems “To Himself”, Byzantina Vindobonensia 23, Vienna.

G. Filotheou, "The God Trodden Mount Sinai Holy Monastery (Saint Catherine)", M. Kazakou - V. Skoulas (eds.), Egeria: Mediterranean Medieval Places of Pilgrimage Network for the Documentation, Preservation and Enhacement of Monuments in the Euromediterranean Area, Athens, 77-78.

E. Foley - M. P. Bangert, Worship Music: A Concise Dictionary, Collegeville.

A. Grabar, L'Empereur dans l'Art byzantin, London.

Ø. Hjort, “The Sculpture of the Kariye Camii”, DOP 33, 199-289.

N. Isar, "Chorography (Chôra, Chôros, Chorós): A Performative Paradigm of Creation of Sacred Space in Byzantium", A. Lidov (ed.), Hierotopy: The Creation of Sacred Space in Byzantium and Medieval Russia, Moscow, 59-90.

L. James, Light and colour in Byzantine Art, Oxford.

D. Janes, God and Gold in Late Antiquity, Cambridge.

I. Kalavrezou-Maxeiner, "Portraits and Portraiture: Donor Portraits”, A. Kazhdan (ed.), The Oxford Dictionary of Byzantium 3, Oxford, 1705.

A. Kazhdan, "Ktetor”, A. Kazhdan (ed.), Oxford Dictionary of Byzantium 2, New York and Oxford,1160.

H. A. Klein, "Sacred Relics and Imperial Ceremonies at the Great Palace of Constantinople", BYZAS 5, 79-99.

H. A. Klein - R. Ousterhout - B. Pitarakis (eds.), Kariye Camii, Yeniden / The Kariye Camii Reconsidered, İstanbul. 
Klein 2015

Lafontaigne-Dosogne 1975

Magdalino 2011

Mango 1959

Matheou et al. 2016

Nelson 1999

Olkinoura 2015

Ousterhout 1987

Ousterhout 1995

Ousterhout 2002

Popović 2010

Schibille 2014

Ševčenko 1975

Teteriatnikov 1998

Teteriatnikov 2003

Trifunović 1973

Underwood 1966

Underwood 1975

Velmans 1977
H. A. Klein, "The Crown of His Kingdom: Imperial Ideology, Palace Ritual and the Relics of Christ's Passion", M. Featherstone - J. M. Spieser - G. Tanman - U. Wulf-Rheidt (eds.), The Emperor's House. Palaces from Augustus to the Age of Absolutism, Berlin, 201-212.

J. Lafontaigne-Dosogne, "Iconography of the Cycle of the Infancy of. Christ", P. A. Underwood (ed.), Studies in the art of the Kariye Djami and its intellectual background, Princeton, 197-241.

P. Magdalino, "Theodore Metochites, the Chora, and Constantinople”, H. A. Klein - R. Ousterhout - B. Pitarakis (eds.), Kariye Camii, Yeniden/The Kariye Camii Reconsidered, İstanbul, 169-87.

C. Mango, The Brazen House: a study of the vestibule of the Imperial Palace of Constantinople, Front Munksgaard.

N. S. M. Matheou - T. Kampianaki - L. M. Bondioli, From Constantinople to the Frontier: The City and the cities, Leiden-Boston.

R. Nelson, The Chora and the Great Church. Intervisuality in $14^{\text {th }}$ century Constantinople, Byzantine and Modern Greek Studies 23, 67-101.

J. Olkinuora, Byzantine Hymnography for the Feast of the Entrance of the Theotokos: An Intermedial Approach. Studia Patristica Fennica 4, Helsinki.

R. Ousterhout, The Architecture of the Kariye Camii in Istanbul, Dumbarton Oaks Studies 25, Washington.

R. Ousterhout, "The Virgin of the Chora: An Image and Its Contexts", R. Ousterhout - L. Brubaker (eds.), The Sacred Image 13, East and West, Urbana, 91-108.

R. Ousterhout, The Art of the Kariye Camii, Istanbul-London.

B. Popović, Visoke kape-klobuci iz manastira Resave i turban Teodora Metohita, Zbornik Narodnog muzeja Beograd XIX / 2, Istorija umetnosti, Beograd, 91-117.

N. Schibille, Hagia Sophia and the Byzantine Aesthetic Experience, Inbunden.

I. Ševčenko, "Theodore Metochites, the Chora, and the Intellectual Trends of His Time", The Kariye Djami, vol. 4, New York, 19-55.

N. Teteriatnikov, "Devotional crosses in the columns and walls of Hagia Sophia“, Byzantion 68, 2, 419- 445.

N. Teteriatnikov, "Relics in Walls, Pillars and Columns of Byzantine Churches", A. Lidov (ed.), Eastern Christian Relics, Moscow, 74-92.

Đ. Trifunović, Žitije Svetog Save Teodorsija Hilandarca, izd. Đ. Daničić, prir. Đ. Trifunović, Beograd.

P. A. Underwood, The Kariye Djami, vol. 3, New York.

P. A. Underwood (ed.), The Kariye Djami, vol. 4, New York.

T. Velmans, Un témoignage sur la société: les images des contemporains, in La peinture murale byzantine à la fin du Moyen Age (Bibliothèque des CahA, 11), Paris, 69-97. 
